\title{
ILLEGAL DETENTION AND THE ADMISSIBILITY OF CONFESSIONS
}

ZEALous police activity in the investigation and punishment of crime creates a continued possibility of invasion of individual civil liberties. This conflict is acutely manifested when the difficult task of detecting and convicting offenders induces police agents and prosecutors to violate or circumvent stautory and judicial rules requiring prompt arraignment of arrested persons. Since early examination of suspects is of great assistance in procuring evidence and eliciting confessions, ${ }^{1}$ public officials often urge that arraignment legislation should be made more flexible or that "technical" violations of the existing statutes should not preclude admission into evidence, in subsequent trials, of illegally obtained testimony..$^{2}$ Functionally, two interrelated problems are involved.$^{8}$ (1) The enunciation of workable regulations governing the arraignment and examination of suspects; and (2) the formulation of rules regarding the admissibility into evidence of confessions obtained directly or indirectly, in violation of the arraignment and examination statutes.

Certain of the various presently applicable federal statutes impose upon lawenforcing officials the duty of bringing arrested persons before committing 4 magistrates or commissioners, "immediately," "forthwith," a or "without delay." " The courts have read an analogous requirement of immediate commitment into the provision of the Judicial Code, regulating arrests by United States marshals and other officials, not subject to specific statutes. ${ }^{8}$ Similar legislation exists in all states. ${ }^{9}$ Examination of persons held in custody is curbed by

1. Hearings before Subcommittee No. 2 of the Committee on the Judiciary, House of Representatives, on H. R. 3690 (78th Congress 1st Session, 1943) passim (cited hereinafter as Hearings). See Hopkins, OuR Lawless Police (1931) 18 et seq.

2. Testimony of Francis Biddle, Attorney General of the United States, in Hearings, op. cit. supra note 1, at 35; testimony of Major Edward Kelly, Sup't of Police, Dist. of Col,, id. at 1-10; Statement of Int. Assoc., Chiefs of Police, id. at 43-4.

3. See Preliminary Draft of Fed. Rules Crim. Proc. (1943) 11-16.

4. "Commitment," or "committal," is the judicial process by which a person is sent to prison. The terms are used in two senses: (1) after a preliminary hearing, a suspect may be committed to await trial before a judge and jury or admitted to bail upon a recognizance; (2) after conviction, a person may be committed to serve the appointed term. Moriarty, PoLICE LAW (7th ed., 1941) 37. The word "arraignment" is often used interchangeably with "commitment" in describing the first of these processes. See Waite, Comment (1944) 42 Mick. L. Rev. 909. The terms arraignment, commitment, and presentment are used interchangeably in this Comment.

5. 49 STAT. 77 (1935), 5 U. S. C. $\$ 300$ (a) (1940). This section regulates arrests by agents of the Federal Bureau of Investigation.

6. 20 STAT. 341 (1879), 18 U. S. C. $\$ 593$ (1940). This section stipulates the procedure to be followed in arresting persons for operating illicit distilleries.

7. D. C. Rev. Stat. (1875) \$397, D. C. CoDE (1940) \& 4-140.

8. 28 StAT. 416 (1894), 18 U. S. C. $\$ 595$ (1940). 
the constitutionally protected privilege against self-incrimination ${ }^{10}$ and by the due process clauses, ${ }^{11}$ which privilege suspects to refuse to answer questions and deny officials the right to interrogate for unreasonably protracted periods, ${ }^{12}$ to use force ${ }^{13}$ or threats ${ }^{14}$ in the course of examination, or to forbid consultation with attorneys and friends. ${ }^{15}$

9. Ala. Code (1940) tit. 15, §160; Artz. Code ANN. (1939) $\$ \$ 44-107,44-140,44-141$; ARK. Dig. Stat. (Pope, 1937) $\S \S 3729,3731$; Cal. Pex. Cone (Deering, 1941) $\$ \S 821-29$; 847-49; Colo. Stat. Ann. (Michie, 1935) c. 48, § 428; Coxn. Gen. Stat. (1930) §239;

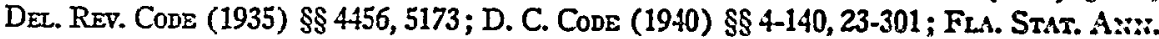
(1943) $\$ \$ 01.06,901.23$; GA. CodE ANN. (Park, Skillman, \& Strozier, 1936) \$\$ 27-210, 27-212; IDAHo CODE ANN. (1932) §§ 19-515, 19-518, 19-614, 19-615; Inc Awu. Stat. (SmithHurd, 1935) c. 38 , $\$ \$ 655,660$; IND. STAt. ANN. (Burns, 1942 repl. vol.) $\$ 9-704$; Iow 4 Codz (1939) $\S \S 13478,13481,13486,13488$; Kans. Stat. ANN. (Corricls, 1935) § 62-610; Ky. REv. Stat. Ann. (Baldwin, 1943) $\$ 26.360,447.010$; Ky. Crmar. Code Awn. (Carroll, 193\$) $\$ \$ 45,46$; LA. Code Crur. Proc. Awn. (Dart, 1932) $\$ \$ 66,79,80$; Mre Rev. Stat. (1930) c. 145, § 9; Mp. ANra. Cone (Flack, 1943 Supp.) art, 661/2, § 260; 11Ass. Ger. Luws (1932) c. $276, \$ \S 22,29,34$; 1IICH. Stat. ANN. (Henderson, 1938) $\$ \$ 28.863,28.872,28.873,28.855$; Minn. Stat. (1941) $\$ \$ 629.39$, 629.46; Miss. Code Ams. (1942) $\$ 2473$; Mo. Rev. Stat. AnN. (1939) \$§ 3862, 38\&3; MoNt. Rev. Code (Anderson and MicFarland, 1935) $\S \S 11731,11739-40$; NerR. Coxrp. Stat. (1929) §29-412; Nev. Cossp. Laws (Fillyer, 1929) $\$ \S 10744-48,10762-64 ;$ N. H. Rev. Laws (1942) c. 423, §13; N. J. Star. Azz:. (1939) $\S 2: 216-9$; N. 11. Stat. Ann. (1941) §42-202, 42-402, 42-1914; N. Y. Crns. Code (1939) \$158-59, 165, 185; N. C. GeN. Stat. (Michie, Sublett \& Stedman, 1943) $\$ \$ 15-24$, 15-46; N. D. CoMrp. Laws Ans. (1913) $\S \S 10543,10548$, 10576, 10578; Onlo Geri. Conz Amz: (Page, 1939) $\$ \$ 13432-3,13432-4$; OrLa. Stat. (1941) tit. 22, $\$ \$ 176-77,181,205$; Ore. Cosrp. Laws Ann. (1940) $\S \S 26-1538,26-1547$; PA. Stat. (Purdon, 1936) tit. 19, $\$ \$ 3,4$; R. I. GeN. Laws ANn. (1938) c. 625, §68; S. C. Cone (1942) $\$ \$ 907,920$; S. D. Conz (1939) $\$ \$ 34.1608,34,1619-24$; TENN. CODE ANN. (Williams, 1934) \$§11515, 11544; TEx. SrnT. (Vernon, 1926) Code Crim. Proc. art. 233-35; Urar Cone Awr. (1943) $\$ \S 105-44$, 105-13-23, 105-15-1; VT. Public Laws (1933) $\$ \$ 2342,2519$; Vt. LAws: (1937) No. 49,

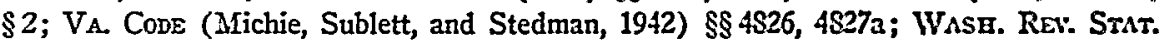
(Remington, 1932) § 1949; W. VA. Code ANN. (Míichie, Sublett, and Stedman, 1943) §§ 243, 6150 ; Wrs. Stat. (1943) $\$ \$ 361.08,364.10,364.14$; Wro. REv. Srat. Amm. (Courtright, 1931) $\S \S 33-108,33-110,33-115$; Wyo. Rev. Stat. ANs. (Courtright, Supp. 1940) $\S \S 33-2110$, 33-2114.

10. U. S. Const. AMrend. V. It has been held that the 14th Amendment does not require the states to grant a privilege against self-incrimination. See Jack v. Kansas, 199 U. S. 372 (1905) ; Banks v. State, 18 Ala. App. 376, 93 So. 293 (1921) ; State v. O'Brien, 105 Vt. 97, 170 Atl. 98 (1934) ; People v. Schade, 292 N. Y. S. 612, 161 Mfise. 212 (1936). However, most state constitutions expressly grant the privilege. See, e.g., Kr. Corsr. $\$ 11$; Mrsur. Const. Art I, 66; N. Y. Const. Art. I, §6; Utar Const. Art. I, § 12.

11. U. S. Const. A.rend. V; AMrend. XIV, § 1.

12. Ashcraft v. Tennessee, 322 U. S. 143 (1944) ; Lisenba v. California, 314 U. S. 219 (1941) ; Bram v. United States, 168 U. S. 532 (1897). This process has been characterized as an "inquisition," analogous to the practice of medieval heresy-hunting agencies. Enoch v. Commonwealth, 141 Va.411, 126 S. E. 222 (1925). See also Pound, Inquisitorial Confessions (1915) 1 CoRs. L. Q. 77.

13. Ward v. Texas, 316 U. S. 547 (1942) ; Brown v. Mississippi, 297 U. S. 278 (1936).

14. White v. Texas, 310 U. S. 530 (1940); Chambers v. Florida, 309 U. S. 227 (1940).

15. Chambers v. Florida, 309 U. S. 227 (1940); Johnson v. Zerbst, 304 U. S. 459 (1938); Powell v. Alabama, 287 U. S. 45 (1932). 
Disclosure at trial of a violation of the arraignment statutes confronts the courts with the task of deciding whether such illegal conduct should result in the automatic exclusion of confessions or evidence thereby obtained, with the consequent reversal of convictions predicated wholly or partly thereon, or whether exclusion and/or reversal should be dependent upon the utilization of directly coercive procedures by the police or prosecutors. The rule in effect in the federal courts until $1943^{16}$ and the rules still in effect in almost all states ${ }^{17}$ made the "voluntariness" of a confession the basic touchstone of its admissibility into evidence. Accordingly, self-incriminatory statements were excluded when they had been made after incommunicado inquisitions, ${ }^{18}$ physical violence, ${ }^{10}$ or promises of immunity or lighter punishment. ${ }^{20}$ However, if a confession were found

16. Ziang Sung Wan v. United States, 266 U. S. 1 (1924) ; Hardy v. United States, 186 U. S. 224 (1902) ; Bram v. United States, 168 U. S. 532 (1897); Wilson v. United States, 162 U. S. 613 (1896).

17. See cases cited infra notes $18,19,20$. In some jurisdictions the burden of proof of demonstrating that a proffered confession was made without the inducement of threats, intimidation, or promises of immunity is on the prosecution. People v. Jones, 150 P. (2d) 801 (Cal. Sup. Ct. 1944) ; see Lang v. State, 178 Wis. 114, 189 N. W. 558 (1922) ; 2 WrARton, Criminal Evidence (1935) §601.

18. Osborn v. People, 83 Colo. 4, 262 Pac. 892 (1927) ; People v. Rogers, 303 Ill. 578, 136 N. E. 470 (1922) ; State v. Scarbrough, 167 La. 484, 119 So. 523 (1928); Ammons v. State, 80 Miss. 592, 32 So. 9 (1902) ; State v. McCullum, 18 Wash. 394, 51 Pac. 1044 (1897).

19. Beckham v. State, 100 Ala. 15, 14 So. 859 (1893) (threat of violence); Rowe v. State, 98 Fla. 98, 123 So. 523 (1929) (beating with rubber hose); White v. State, 129 Miss. 182, 91 So. 903 (1922) ("water-1cure" administered by vigilantes); People v. Cohen, 243 App. Div. 245, 276 N. Y. S. 851, 855 (2d Dep't 1935) (severe beating) ; State v. Brittuin, 117 N. C. 783, 23 S. E. 433 (1895) (husband threatened to abandon wife unless she confessed incest with her father) ; State v. Smythe, 148 Wash. 65, 268 Pac, 133 (1928) (slappine face) ; State v. Clarissa, 11 Ala. 57 (1847) (whipping); Hector v. State, 2 Mo. 108 (1829) (lashing all night).

The degree to which such practices are utilized by the police is generally unappreciated by laymen. "In various cases which occurred between 1920 and 1930, the Wickersham Commission found that suspected persons had been starved, kept awake many days and nights, confined in pitch-dark and airless cells; had been beaten with fists, clubs, blackjacks, rubber hose, telephone books, straps, whips, beaten on the shins, under the knee cap (at the point of the patellar reflex), across the abdomen, the throat, the face, the head, the shoulders, above the kidneys, on the buttocks and legs; had had their arms twisted, their testicles twisted and squeezed; had been given tear-gas, scopolamin infections and chloroform; had been made to touch corpses and hold the hands of murdered persons in morgues; that women had been lifted by the hair; in one case, a man had been laid flat on the floor and lifted repentedly by his organs of sex. This in modern America between 1920 and 1930, in the fifteenth decade of the Constitution, and for the purpose of obtaining 'voluntary' confessions of guilt." Hopkins, Our Lawless Poltce (1931) 25. See also Bullock v. United States, 122 F. (2d) 213, 215 (App. D. C., 1941) ; Perrygo v. United States, 2 F. (2d) 181 (App. D. C., 1924);

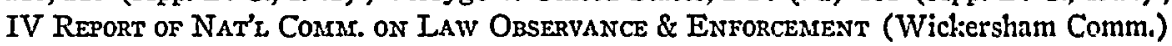
(1931) 170 et seq. ; Lowell, Judicial Use of Torture (1897) 11 HARv. L. REv. 220, 290.

20. Kelly v. State, 72 Ala. 244 (1882); People v. Thompson, 84 Cal. 598, 605 (1890); Beery v. United States, 2 Colo. 186 (1873); Green v. State, 88 Ga. 516 (1891); Rector v. Commonwealth, $80 \mathrm{Ky} .468$ (1882); Biscoe v. State, $67 \mathrm{Md} .6$ (1887); Commonwealth v. 
to have been "voluntarily" made, illegalities attendant upon its procurement were relevant only in a subsequent civil action against the misfeasant officials, ${ }^{21}$ or as a possible basis for obtaining the sympathy of the jury, the sentencing judge, or the paroling or pardoning officials. There was also the possibility that exposure of the illegal detention would induce dismissal of the culpable officers by their superiors ${ }^{22}$ - a remedy which might deter future transgressions and protect civil liberties, but which was useless to the convicted persons.

\section{Recent Supreme Court Cases}

But in its decisions in the Spring of 1943, in the twin cases of MICNabb 2. United States ${ }^{23}$ and Anderson v. Unitcd States, ${ }^{24}$ the Supreme Court departed from the older discretionary standard and held that violation of the arraignment

Nott, 135 Mass. 269 (1883) ; People v. Wolcott. 51 Mlich. 612 (1883) ; State v. Yorl, 37 N. H. 175 (1858) ; People v. Reilly, 224 N. Y. 90, 120 N. E. 113 (1918) ; State v. Dralse, 113 N. C. 624 (1893); Vaughan v. Commonwealth, 17 Gratt 576 (Va. 1867); State v. Mav, 41 Wyo. 365, 285 Pac. 992 (1930).

21. People v. Mrummiana, 258 N. Y. 394, 180 N. E. 94 (1932); Honeycult v. State, 67 Tenn. 371 (1875) ; State v. Sanders, S4 N. C. $72 S$ (18S1); Commonwealth v. Howe, 132 Mass. 250 (18s2); State v. Patterson, 73 MIo. 695 (18S1) ; State v. Revells, 35 La. An. 302 (1883).

22. Testimony of Hon. Sam Hobbs, Representative from Alabama in Hcarirgs, of. cit. supra note 1,18-19. It is probable, however, that this sanction is rarely involed. Chafce et al. Memorandwm on Detention of Arrested Persons in A STatene: on tHe BILI of Rights of the Asierican BAR Assochation on H. R. 3960 (1944) 18. (Hereafter cited as Memorandinn).

23. 318 U. S. 332 (1943). The MICNabb case has not indused state courts to abandon the "voluntariness" criterion. See State v. Browning, 178 S. 11 . (2d) 77 (Arls Sup. Ct. 1944) ; People v. Jones, 150 P. (2d) S01, 804-05 (Cal. Sup. Ct. 1944). It is unlilicly that the admission of confessions after illegal detentions would be considered such a violation of the "fundamental principles of liberty and justice" as to require reversal of state court convictions grounded thereon under the Fourteenth Amendment. See Buchalter v. New Yorl;, 319 U. S. 427 (1943) ; Hebert v. Louisiana, 272 U. S. 312, 316 (1926) ; Hurtado v. California, 110 U. S. 516 (1884).

However, in Ashcraft v. Tennessee, 322 U. S. 143 (1944), the court held that a confession obtained after 36 hours of unremitting questioning was "inherently coercive" and barred by the Fourteenth Amendment. Since the majority opinion specifically refuced to "resolve any of the disputed questions of fact," it is clear, as Mr. Iustice Jackson indicated in his dissent that the court has created an irrefutable presumption of lav that a coniession obtained after 36 hours of questioning is involuntary. This marks a significant departure, in the handling of civil liberties issues arising out of the conduct of eriminal trials in the state courts, from such cases as Chambers v. Florida, 309 U. S. 227 (1940) and Lisenba v. California, 314 U. S. 219 (1941), where the Supreme Court overrode the findings of fact as to fairness.

It is interesting to note that Mr. Justice-Reed-the lone dissenter in the McNobb and Anderson cases-went along with the majority opinion in the Asheraft case. The dissenters in the latter case were Justices Jackson, Frankfurter and Roberts, apparently applying again the philosophy of their dissent in West Virginia State Board of Education v. Barnette, 319 U. S. 624 (1943).

24. 318 U. S. 350 (1943). 
statutes tainted confessions secured during illegal detention so as to make their admission reversible error per $s e .^{25}$

The record on appeal in the $M c N a b b$ case indicated that the defendants had been subjected to intensive interrogation for several days after arrest, without previous arraignment, in seeming violation of the federal statutes. ${ }^{26}$ During this period of apparently illegal confinement, the suspects-semi-literate and unsophisticated Tennessee mountain moonshiners-were subjected to unremitting questioning; they neither requested, nor were informed that they were entitled to the assistance of counsel. ${ }^{27}$ Eventually admissions of guilt were elicited from the suspects; these confessions were admitted into evidence, over objections at trial, and constituted the basis of the Government's case. Both in the trial court and on appeal, ${ }^{28}$ the defendants' sole argument was that the "pressures" employed by the federal agents barred the confessions under the Fifth Amendment. The Constitutional question was by-passed in the majority opinion in the Supreme Court. ${ }^{20}$ Instead the decision was predicated upon the Court's traditional implied power to formulate rules of evidence for federal crininal trials. ${ }^{30}$

In the Anderson case, ${ }^{31}$ the Supreme Court held that confessions of persons -accused of depredating property of the Tennessee Valley Authority during a miner's strike-were inadmissible in a federal trial, where there had been pro* longed detention by county officials in violation of state statutes, ${ }^{32}$ and pre-

25. "Plainly, a conviction resting on evidence secured through such a flagrant disregard of the procedure which Congress has commanded cannot be allowed to stand without making the courts themselves accomplices in willful disobedience of law." McNabb v. United States, 318.U. S. 332,345 (1943).

26. The statutes mentioned were: 48 STAт. 1008 (1934); 5 U. S. C. $\$ 300 \mathrm{a}$ (1940); 28 Stat. 416 (1894), 29 STat. 184 (1896), 31 Stat. 956 (1901), 18 U. S. C. \$ 595 (1940); 20 STAT. 341 (1879), 18 U. S. C. $\$ 593$ (1940).

The $M c N a b b$ case was actually decided upon a misapprehension of the facts as the Mc$\mathrm{Nabb}$ brothers had been arraigned by proper and timely procedure. However, the record failed to show the arraignment. Testimony of Attorney General Biddle, Hearings, op. cit. supra note 1,3-4. Upon retrial the confessions were admitted in evidence and the defendants were convicted of manslaughter. This conviction has been upheld on appeal, McNabb $v$. United States, 142 F. (2d) 904 (C. C. A. 6th, 1944).

27. McNabb v. United States, 318 U. S. 332, 335 (1943).

28. McNabb v. United States, 123 F. (2d) 848 (C. C. A. 6th, 1942).

29. "It is true, as the petitioners assert, that a conviction obtained in the federal courts, the foundation of which is evidence obtained in disregard of liberties deemed fundamental by the Constitution, cannot stand . . . In the view we take of the case, however, it becomes uninecessary to resolve the Constitutional issue pressed upon us." McNabb v. United States, 318 U. S. 332, 339, 340 (1943).

30. Ex parte Bollman and Swartwout, 4 Cranch. 75, 130-31 (U. S. 1807); United States v. Palmer, 3 Wheat. 610, 643-44 (United States 1818); Funk v. United States, 290 U. S. 371 (1933). See also Thayer, Preliminary Treaties on Evidence (1898) 530-31

31. 318 U. S. 350 (1943).

32. "No person can be committed to prison for any criminal matter, until examination thereof be first had before some magistrate." TENN. CoDE ANN. (Williams, 1934) § 11515. This law has been strictly construed as barring pre-arraignment examination. Polk 
arraignment interrogation by these officials in collaboration with agents of the Federal Bureau of Investigation.

Dicta in the $M C N a b b$ and $A n d c r$ son cases seemingly elevated deterrence of illicit conduct by law-enforcing officials to a position co-ordinate with the insulation of suspects from unfair pre-trial treatment as an independent reason for exclusion of extra-judicial confessions. However, since the records on appeal in both cases supported the inference that the barred confessions had been involuntarily extorted ${ }^{33}$ and since strict compliance with the terms or constructions of the arraignment statutes is sometimes impossible, ${ }^{34}$ divergent interpretations of the "MICNabb" doctrine emerged in subsequent decisions in the lower federal courts. Apparently motivated by the desire to prevent hypertechnical requirements from hampering apprehension and punishment of criminals, some courts invoked familiar precedents to write a "rule of reason" inio the nascent "absolute illegality" doctrine. Thus in United States $v . K 7 c c^{35}$ a district court overruled the argument that a confession was barred whenever it had been obtained after pre-arraignment questioning. The implication of the decision was that detentions became illegal, and extra-judicial confessions inadmissible, only when there was gross delay in bringing suspects before committing officials. ${ }^{36}$

Conversely, in other inferior federal tribunals, the social objective of protecting society from crime was wholly subordinated to the desideratum of curtailing lawless conduct by law-enforcing officials. Especially in two recurrent situations, the $M c N a b b$ case was construed as laying down the mechanistic formula that any type of illegal detention of a suspect required preclusion of his confession. The most questionable application came in a series of cases reversing convictions based on apparently uncoerced confessions, made while arraignment was delayed because of the unavoidable absence of the Commissioners on weel: days or because the arrest had occurred on Sunday or late on Saturday..$^{37}$ In

v. State, 170 Tenn. 270, 94 S. W. (2d) 394 (1936) : State ex rel. Morris v. National Surety Co., 162 Tenn. 547, 39 S. W. (2d) 581 (1931).

33. MiNabb v. United States, 318 U. S. 332, 333-38 (1943) ; Anderson v. Unitcd States, 318 U. S. 350, 353-56 (1943). The invalidity of this inference in the MeNabb case is indicated by the conviction of the $\mathrm{M}$ ICNabbs, on retrial. See note 26, supra.

34. See infra note 37 and accompanying text.

35. 50 F. Supp. 679 (E. D. Wash. 1943).

36. "The Government's position is that by the McNabb decision the Supreme Court simply added to the criteria by which the voluntary or involuntary nature of a confession is to be judged an additional yardstick to assist the court in its process of measuring. The Government argues that any other appraisal of the ArcNabb decision would malse of it an unworkable barrier to the reasonable administration of criminal justice... After careful study of the MICNabb opinion, I have concluded that the Government's position is correct . . ." United States v. Klee, 50 F. Supp. 679,683 (E. D. Wash. 1943).

37. Many of these cases arose in the District of Columbia where the city police officials are subject to federal laws. See supra note 7. In one case, where the accused was arrested at $5: 00 \mathrm{P}$. M1. on a Saturday afternoon and arraigned at $11: 30 \mathrm{~A}$. MI. Monday, it was held that his confession, made at 8:00 P. Mr. on the day of arrest, was inadmissible for any purpose. United States v. Meely, No. 72187, United States District Court, District of Columbia 
all these cases arraignment had taken place at an early hour on the next business day. In another group of decisions, it was held that a voluntary declaration of guilt immediately after arrest was rendered inadmissible nunc pro tunc by a subsequent unnecessary delay in arraignment. ${ }^{38}$

This retroactive illegality test was rejected by the Supreme Court in the Spring of 1944 in United States $v$. Mitchell. ${ }^{39}$ The defendant had confessed a few minutes after arrest and arrival at a District of Columbia police station. Thereafter, he was illegally retained in custody for eight days before being accorded a preliminary hearing. The decision of the Circuit Court of Appeals ${ }^{40}$ that the admission of guilt had been improperly received in evidence was reversed with the Delphic declaration that "the foundations for application of the $M c N a b b$ doctrine [were] ... here totally lacking ... there was no disclosure induced by illegal detention, no evidence was obtained in violation of any legal rights, . . . " 41

Doubtless Mr. Justice Frankfurter's opinion in the Mitchell case was intended, inter alia, to restrain trial juges from acting precipilously in excluding confessions, under the influence of his own hortatory language in the $\mathrm{McNabb}$ case. Yet because it gave birth to a new formula for determining admissibility -the "inducement by detention" test-the net effect of the Mitchell decision may be to expand the penumbra of uncertainty in which federal peace officers oper-

(1943). See also United States v. Johnston, No. 431303, Municipal Court, District of Columbia (1943) ; United States v. Wilburn, Nos. 71877, 72342, United States District Court, District of Columbia (1943).

In one case in the Southern District of New York, the accused was arrested at 7:00 A. M. and arraigned at 1:00 P. M. the same day; despite the fact that the delay in arraignment was said to have been caused solely by the absence of the Commissioner, the court excluded all evidence of confessions made between arraignment and arrest. United States v. Fedorka (S. D. N. Y.), July 19, 1943. See also United States v. Corn, 54 F. Supp. 307 (E. D. Wisc. 1944) ; United States v. Hart, N. D. Ill., May 3, 1943.

38. United States v. Haupt, 136 F. (2d) 661 (C. C. A. 7th, 1943) (McNabb case criticized, but followed); Gros v. United States, 136 F. (2d) 878 (C. C. A. 9th, 1943); United States v. Hoffman, 137 F. (2d) 416 (C. C. A. 2d, 1943); Runnels v. United States, 138 F. (2d) 346 (C. C. A. 9th, 1943).

39. 322 U. S. 65 (1944). Mr. Justice Reed, who had dissented in both the $M I c N a b b$ and Anderson cases, wrote a concurring opinion in the Mitchell case. Asserting his belief that the former "voluntariness" criterion should be reinstated, Justice Reed said in his McNabb dissent: "I question whether this [detention test] offers to the trial courts and the peace officers a rule of admissibility as clear as the test of the voluntary character of the confession." McNabb v. United States, 318 U. S. 332, 349 (1943). In the Mitchell case, Justice Reed said: "The juristic theory under which a confession should be admitted or barred is bottomed on the testimonial trusworthiness of the confession. If the confession is frecly made without inducement or menace, it is admissible." United States v. Mitchell, 322 U. S. 65,71 (1944).

40. Mitchell v. United States, 138 F. (2d) 426 (App. D. C. 1943). This decision was predicated on the alleged mandate of the $M c N a b b$ case.

41. Mitchell v. United States, 322 U. S. 65, 69, 70 (1944). 
ate. At least the MINabb decisions taken literally, had the virtue of definiteness in barring all confessions made after protracted detention, save possibly where uncontrollable extrinsic factors were responsible for the delay in arraignment and prevented it from becoming illegal. 22 But there is language in the Mitchell case which can reasonably be construed as permitting admission of confessions made during illegal detention, provided that the delay in arraignment were found not to have "induced" the confession. If this result were intended by the Court, "inducement by detention" is merely a new verbal symbol for the old "voluntariness" test. ${ }^{43}$ Instead of serving as an independent basis for exclusion, the " $M c N a b b$ doctrine" will then have been reduced to the status of a presumption of law that where illegal detention has been continued for a certain period, confessions obtained thereafter are conclusively deemed to have been "involuntary:"

If Congress continues to ignore investigative realities-e.g., the occasional necessity for immediate interrogation or for short term incommunicado detention to prevent escape of confederates-the courts have no option but to modify the over-rigid arraignment statutes, under the guise of formulating rules of evidence. Yet the confusion which has followed in the train of the $I I c . \mathrm{Vab}, A n$ derson, and Mitchell cases clearly indicates the limited competence of appellate courts at evolving consistent and useable arraignment rules, ${ }^{4 / 2}$ in the process of reviewing the minor proportion of convictions which are taken on appeal.

\section{Proposed Solutions}

The uncertain balance between the societal interest in protecting individual civil liberties and the interest in apprehending criminals struck in the recent Supreme Court decisions has evoked widespread controversy and produced a number of alternate solutions. ${ }^{45}$ For the most part, the debate has centered about the evidentiary issues, and there has been insufficient attempt to evaluate the desirability of modification of the arraignment statutes or to consider procedures other than exclusion which can.protect suspects.

42. In his dissenting opinion, Mrr. Justice Reed interpreted the $M(c N a b b$ decision as categorically excluding all confessions made after delayed arraignments. MreNabb v. Cnited - States, 31 S U. S. 332, 349 (1943).

43. In Sykes v. United States, 143 F. (2d) 140 (App. D. C. 1944), citing the Mfitehell case, the "inducement by detention" test was applied as superseding that of the MIeNalth case. No point was made of the similarity of the new criterion to the old norm of "voluuttariness."

44. Compare Conmiager, Mijuorty Rule and Minouity Rigats (1943) 65-\$3.

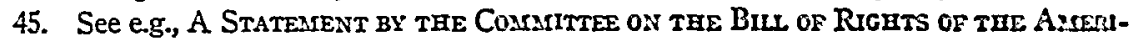
CAN BaR Associatron on H. R. 3690 (1944); Malloy, MfeNabb v. U. S.-The Fedcral Rule of Admissibilitity of Confessions (1943) 27 MAarg. L. Rev. 212; Mraschinot, MeNabb v.U.S. (1943) 21 Cer-Kent Rev. 340; Admissibility of Illegally Obtaissd Confessions: The Hobbs Bill (H. R. 3609) (1943) 3 Law. Guwb Rev. No. 6, 48; Waite, Comments (1944) 42 Mícr. L. Rev. 679, 909. See also (1944) 18 Texx. L. Rev. 212; (1944) 42 MIL H. L. RE. 717; (1943) 28 MINN. L. Rev. 73. 
- The Hobbs Bill. The police viewpoint was embodied in the Hobbs Bill,40 introduced at the present Congressional session, which sought to restore the law to its pre-McNabb status. The Bill proposed that "no failure to observe the requirement of law as to the time within which a person under arrest must be brought before a magistrate, commissioner, or court, shall render inadmissible any evidence that is otherwise admissible." Leaders of the Bar, including the Attorney General, objected to the proposed statute because of the probability that its enactment, by removing the most effective present sanction against official misconduct, would reopen the door to prolonged incommunicado detentions. ${ }^{47}$ The bill also seems objectionable as an unwarranted interference with the judicial power of formulating evidentiary rules for criminal proceedings.

Rule 5 of the Proposed Rules of Criminal Procedure. The Supreme Court's Advisory Committee on Rules of Criminal Procedure has proposed two compromise solutions of the dilemma. ${ }^{48}$ In both drafts, Rule 5 qualifies the present arraignment statutes by requiring that suspects be taken before a commiting officer "without unnecessary delay." 49 The original draft contained a further provision categorically rendering inadmissible any statement made in response to interrogation, during a period of illegal detention. ${ }^{50}$ This formulation, however, gave reasonable leeway to police and prosecuting attorneys by permitting interrogation to continue until the point where the delay in commitment became unreasonable. Presumably confessions obtained in the weekend-arrest or late evening-arrest cases were thereby made admissible, but the ultimate power to $\mathrm{d}$ termine when detention became illegal was vested in the judiciary. In addition, the wording of the first draft of Rule 5 permitted admission of voluntary confessions or declarations not made in response to interrogation, regardless of whether detention was illegally protracted. ${ }^{51}$

46. H. R. 3690, 78th Congress, 1st Session, introduced by Representative Hobbs of Alabama on November 18, 1943. The bill was reintroduced by Congressman Hobbs at the 2nd Session of the 78th Congress and reassigned the number, H. R. 3690. The House Committee on the Judiciary reported the bill favorably on May 24, 1944, after amending it to read as follows:

"To safeguard the admission of evidence in certain cases be it enacted by the Senate and House of Representatives of the United States of America in Congress assembled that the failure to observe the requirement of law to the time within which a person under arrest must be brought before a magistrate, commissioner, or court shall not render inadmissible any evidence that is otherwise admissible."

The bill has not been introduced in the Senate.

47. Hearings, op. cit. supra note 1 , at 9, 61, 64, 83 .

48. Preliminary Draft of Fed. Rules Crtm. Proc. (1943); Second Draft of Fed. Rutes Crim. Proc. (1944).

49. Preliminary Draft of Fed. Rules Crum. Proc. (1943) Rule 5 (a); Second Draft of Fed. Rules Crim. Proc. (1944) Rule 5. Compare wording of statutes cited supra notes $5,6,7,8$.

50. Pretiminary Draft of Fed. Rules Crimr. Proc. (1943) Rule 5(b).

51. Pretinimary Draft of Fed. Rutes Crim. Proc. (1943) Note at 13-14. 
The provisions regulating the admissibility of confessions made during illegal detentions were, however, deleted in the second draft of the Proposed Rules. This made Rule 5 little more than a new arraignment statute, utilizing a somewhat liberalized "without unnecessary delay" time criterion. But the deletion of subsection 1 (b) of the original draft relegated the Courts to the haphazard process, begun in the $M c N a b b$ case, of defining a satisfactory admissibility test.

Apparently motivated by the belief that some degree of early examination was essential, Professor Waite, a member of the Advisory Committee on Rules of Criminal Procedure, proposed that committing officers be empowered to interrogate suspects at the preliminary hearing, after warning that any statements might be used in evidence. ${ }^{52}$ This recommendation was rejected by the Committee majority on the grounds that it probably violated the privilege against self-incrimination and that the non-legal training of many Commissioners made it undesirable to endow them with investigative powers. ${ }^{53}$

The English Practice. Criminologists and jurists concerned about the need for reform of the arraignment procedure have suggested that attention be given to the more flexible English procedures. ${ }^{5}$ The British peace-time statutes contain no express requirement for immediate presentment where there is an arrest pursuant to warrant, ${ }^{55}$ but persons taken into custody without warrants must be arraigned within 24 hours after arrest. ${ }^{50}$ Where this is impossible, the local Superintendent or Inspector of Police is required either to release the suspect on a recognizance ${ }^{57}$ or, where the crime appears to be serious in nature, bring him before a court of summary jurisdiction "as soon as practicable." is

52. Pretintmary Draft of Fed. Rules Crrar. Pruc. (1943) 253. Analugous rules had been suggested by other students. Pound, Crminal. Justice In Aurnica (1930) 85; Judge Simeon Baldwin in 6 A. B. A. Rep. (1883) 225, 23S; NAT'L Cosss. o: Law Ogservaance \& ENForcenIent, Rep. No. 11 (1931) 5; 3 Wigarore, Evideice (3d ed. 1940) 319-20.

53. Prelaminary Draft gr Fed. Rules Crm. Proc. (1943) 253-54.

54. Mr. Justice Frankfurter suggested the impurtance of studying the English practice in the MicNabb case. McNabb v. United States, 318 U. S. 332, 345 (1943). See alsu Waite, Comment (1944) 42 MICH. L. Rev. 679 ; testimony of Pressman, Hcarings, of cir. supra note 1 , at 97 ; testimony of Hobbs, id. at 25.

55. The arrest statutes, however, contain language analogous to that of $18 \mathrm{U}$. S. C. 595 , invoked by the court in support of the exclusionary rule in the Mratabb case. See 4 HalsbURY's StatuTES (1929) 481, 482-\$3, 486-\$7.

In Scotland, on the other hand, strict rules protect persons arrested with or without warrants. Interrogation of arrested persons by the police is forbidden, and confessions and admissions obtained in this way are inadmissible in evidence. Kerdy, Crnsmal PLocedorn. in Scotland (1913) 16, 17, 18 ; Renton \& Brown, Crmsmal Procedune Accozonig tu the LAw or ScotLand (1928) 28, 29, 33-35.

56. The prisoner must be taken before a court of summary jurisdiction "as soon as practicable after he is . . . taken into custody." Summary Jurisdiction Act, 1879, 42 \& 43 Vrct., c. $49 \S 38$. This period may not be extended beyond twenty-four hours. Ibid.

57. Ibid.

58. Criminal Justice Administration Act, 1914, 4 \& 5 GEov, c. 58, §22. See also Metropolitan Police Act, 1839, 2 \& 3 Vicr., c. 47. ss. 70, 71; Mf́nicipal Corporations . let, 1882, 45 \& 46 VICT., c. 50, \$277; Summary Jurisdiction Act, 1882, 45 \& 46 VIст., c. $50, \S 9$. 
In addition, special wartime statutes permit detention for as long as nine days, providing authorization is obtained from local police executives and reported to the Home Minister. ${ }^{50}$

The English cases dealing with extra-judicial confessions, although characterized by ambiguity, attempt to distinguish between pre- and post-arrest interrogation. Police officials are permitted to question suspects to determine whether there are reasonable grounds for their arrest, and admissions made during stuch preliminary inquiries may be introduced into evidence. ${ }^{60}$ On the other hand, in Regina v. Gavin, ${ }^{61}$ the Court of Queens Bench interpreted as involuntary a confession given in response to interrogation immediately subsequent to arrest.02 But while the police were thus restricted in questioning arrested persons, they have been permitted to cross-examine for the purpose of removing ambigtities in voluntary statements. Such statements and all gratuitous declarations by prisoners are admissible in evidence. ${ }^{33}$ To avoid the rule against post-arraignment questioning, police in London and a number of other cities developed the practice of "detaining" suspects without arrest, on their own initiative. ${ }^{64}$ Although this star-chamber procedure was strongly criticized ${ }^{\text {os }}$ by a Royal Commission, confessions made during the period of detention have been held admissible. $^{68}$

The dissimilarity of criminal organization in England and the United States ${ }^{07}$ and the divergence in basic conceptions as to the proper functions of prosecuting officials ${ }^{68}$ vitiates the British experience as a guide to American legislators. That

59. Sec. 18(o) Defensè Regulations (1939), 34 Halsbury's Statures (1941) 642.

60. However, a standard of "voluntariness" is employed. Rex. v. Voisin, [1918] $1 \mathrm{~K}$. B. 531; Rex. v. Warickshall, 1 Leach 263, 168 Eng. Rep. R. 234 (1783); Reg. v. Thompson [1893] 2 Q. B. 12.

61. 15 Cox C. C. 656 (1885). See also Reg. v. Male, 17 Cox C. C. 689,690 (1893).

62. "When a prisoner is in custody the police have no right to ask him questions. Reading a statement over, and then saying to him, 'what have you to say ?' is cross-examining the prisoner, and therefore shut it out. A prisoner's mouth is closed after he is once given in charge, and he ought not to be asked anything." Reg. v. Gavin, 15 Cox C. C. 656, 657 (1885).

63. Reg. v. Male, 17 Cox C. C. 689 (1893). For an excellent summary of the English law regarding the admissibility of confessions, see TAYLOR, EvidENCE (12th ed., 1931) $\S 862-901$.

At the request of the Home Secretary, the Judges of the Kings Bench issued in 1912 a series of advisory rules for the guidance of police officers. These Judges' Rules were amended in 1918. In 1930, an explanatory circular was issued by the Home Office, with the approval of the Judges. See 6 PoLrce Jour. (1933) 342, 350 et seq.

64. See Rex. v. Voisin, [1918] 1 K. B. 531.

65. Report of the Royal Consission on Police Powers and Procedule (1929) Cmd. 3297 at 55-61.

66. Ibrahim v. Rex, [1914] A. C. 599, 609 P. C.; Rex. v. Voisin, [1918] I K. B. 631.

67. The "gang" criminality of the United States is a unique characteristic of the American problem.

68. Under the English practice, the Crown prosecutors handle only a minor percentage of the total number of criminal cases. The position of prosecutor is not a stepping stone to political preeminence, and accordingly lesser emphasis is placed on the percentage of convictions. See Howard, Criminal Justice in Engrand (1931) 4-15, 387. 
experience, however, underscores the unworkability of over-rigid rules and the incapacity of the Judiciary to resolve the conflicting interests involved without legislative assistance.

\section{ConcLusion}

The gulf between judicial conceptions of fairness and common police practice suggests the desirability of drafting legislation which will grant the police reasonable leeway in arraignment and early interrogation of suspects without unduly invading individual rights. ${ }^{69}$ The Attorney General has suggested replacement of the present group of arraignment statutes by a single law providing that presentment must take place "within a reasonable time." 70 It was suggested that in unusual cases, this might permit prolongation of detention for as much as eight or nine days, without resort to a magistrate. Of course, to effectuate such secluded interrogation, it would be necessary to abrogate the Constitutionally guaranteed rights of habeas corpus, consultation with counsel, and release on bail. It is highly doubtful that such legislation would or shuuld be adopted, or could survive judicial review. ${ }^{71}$

Indeed, except in dealing with unusual situations, ${ }^{72}$ it is difficult to see why police officers should be permtited to keep suspects in custody without arraignment for more than 24 hours. $^{73}$ For if incommunicado detention is protracted beyond this point, Mr. Justice Frankfurter's assumption in Ashcruft $\approx$. Tenues$\mathrm{see}^{7^{\mathrm{A}}}$ that a confession loses its voluntary character becomes psychologically justifiable. The history of committal legislation indicates that the language in the draft of Criminal Procedure Rule 5 directing arraignment "without unnecessary delay," would probably be interpreted to permit procrastination only because of the unavailability of Commissioners. ${ }^{75}$ Hence, if a $2+$-hour preliminary investigation period is to be allowed, specified authority should be provided in Rule 5 or the arraignment statutes.

69. Memorandum, op. cit. sipra note 22, at 1.51; compare, Juesson, TuE ALAcnurien: of JUSTICE IN ENGLAND (1940) 141: "It is doubtful whether the police could do their worl: efficiently if they did not develop practices for which there is no legal authority ... If the police are to respect the law, it will be necessary to redefine and probably enlarge their powers." See also Solicitor, The Right to a Fair Trial in Pewsl Refows ri: Eraglazo (cd. by Radzinowicz and Turner, 1940) 81.

70. Hearings, op. cit. supra note 1 , at $35-38$.

71. Compare id. at 38 .

72. See infra pp. 770-771.

73. After arraignment the prisoner is taken from the custody of the police and either released on bail or placed under the supervision of the marshal. Since the marshal lad:s motives for seeking convictions and since the prisoner is entitled to see counsel and firiends, protracted questioning and the use of third degree methods rarely occur after arraignment. See Report of the Nat'l Coars. on Law Observatice atrd Eirroscerdent (1931) No. 11, 169, 210-11; but see Hearings, op. cit. stipra note 1, at 13.

74. 322 U. S. 65 (1944).

75. See supra note $S$. 
Unquestionably there are a few exceptional situations when the Federal Bureau of Investigation should be permitted, subject to appropriate restrictions, to prolong incommunicado custody. In the first place, the interests of national defense occasionally require secrecy in the investigation of sabotage plots or treasonable activities. The ordinary mechanism of the arraignment statutes impedes effective investigation in numerous ways: committal is usually accompanied with publicity which may serve to warn members of a loosely-knit espionage gang, enabling them to escape, destroy damaging evidence, or even intimidate or kill witnesses for the government. ${ }^{76}$ Furthermore, the officers may have difficulty in immediately establishing probable cause against an arrested person, who is believed to be part of, or know a great deal about a conspiracy. When confronted with this problem in the investigation of the Quirin case, ${ }^{77}$ the Attorney General found it necessary to direct disregard of the law "requiring me to arraign all of them immediately, for the preservation of the country." 78

Special provision could readily be made for dealing with seditious activities without extending the statutory time-limit of permissive detention for other federal and District of Columbia offenses. The most feasible technique would appear to be devisal of a statutory proceeding for "investigatory imprisonment," which would permit the $F$. B. I. to detain a suspect without presentment for a period not exceeding eight days. ${ }^{79}$ The Bureau should be permitted to exercise this extraordinary power only upon obtainment of a special warrant of arres: Although executive officers were given unfettered power to utilize procedures analogous to the proposed "investigatory imprisonment" during the Civil War ${ }^{80}$ and similar procedures have been devised in Great Britain during both World Wars, ${ }^{81}$ it would be safer to require that the special warrants could be issued only by federal judgés. ${ }^{82}$

76. See Perkins, Elements of Police Sctence (1942) 300.

77. Ex parte Quirin, 317 U. S. 1 (1942). Eight Nazi saboteurs were arrested over a period of eight or nine days; none were arraigned until all were captured. If arraignment had been held promptly, some of the saboteurs might have escaped. See Hearings, op. cit. stlpra note 1 , at $35-36$.

78. Hearings, op. cit. supra note 1 , at 36 .

79. See Memorandinm, op. cit. supra note 22, at 37 .

80. By proclamation, President Lincoln suspended habras corpus "in respect to all persons arrested, or who are now, or hereafter during the rebellion shall be, imprisoned in any ... place of confinement by any military authority ..."13 STAT. 730 (1861). Congress later authorized Lincoln to suspend habeas corpus "whenever, in his judgment, the public safety may require it. 12 Star. 755 (1863). The exercise of these powers by executive officers is discussed in Randall, Constitutional Problems Under Lincoln (1926) c. VII; 2 Morrison, Oxford Fistory of the United States (1927) 255; Corwin, The President (1940) 185-89.

81. Parliament authorized the cabinet to promulgate regulations suspending even Magna Charta's requirement that "no free man shall be taken or imprisoned or dispossessed, or outlawed, or banished, or in any way destroyed . . . except by the legal judgment of his pecrs or by the law of the land." Emergency Defense Act of 1939, $\$ 1,34$ Harsbury's Statutes (1941) ; Defense Regulations of 1939, \& 88c, 34 Halsbury's Statutes (1941). 
A second special problem exists whenever the police are seeking to apprehend accomplices of an arrested suspect. It has been suggested that public arraignment will warn other members of the gang. ${ }^{33}$ However, the advantages of speedy presentment could be retained, without hampering the police, if legislation were enacted authorizing Commissioners to hold the preliminary hearing in the jail or permitting remission of the suspect, after arraignment, for a limited period of incommunicado detention. ${ }^{84}$ Presence of a gang-retained lawyer might permit information of the arrest to reach the remainder of the gang. Accordingly it might be desirable to withdraw temporarily the prisoner's right to select his own counsel and direct the Commissioner to designate an attorney to represent his interests. ${ }^{85}$ To present abuse it would again appear desirable to require issuance by the Court of a special order for prison arraignment or limited postarraignment detention. ${ }^{\text {so }}$

Concomitant to revision of the arraignment statutes is the problem of devising more effective sanctions to assure compliance with the requirement of lawful presentment.st The fact that the $I I c N a b b$ rule is the only effective sanction now operating does not, of course, make its retention desirable.

Several shortcomings of the exclusionary device are apparent. In the first place, exclusion does not directly punish the official who unlawiully obtained a confession, whereas it may force the public to incur a double expense by paying for a new investigation and trial. ${ }^{.8}$ Secondly, the $M i c N a b b$ rule may interfere with the effective conduct of the trial by focusing the attention of the judge and

82. The latitudinarian nature of the powers possessed by the British Mfinistry of Home Security was severely criticized by Lord Athin in his dissenting opinion in Liversidge $v$. Anderson, [1942] A. C. 206, 244. See also Pound, Administratize Lliscretion and Cizil Liberties in England (1943) $56 \mathrm{HARv}$. L. REv. SO6; cf. MIornson:, up. cit. supra note 80 , at 255.

83. Testimony of Attorney General Biddle in Hearings, of. cif. suspo note 1 , at 36 .

84. See Memorandum, op. cit. supra note 22, at 39-40.

85. But query whether such an arrangement would survive judicial scrutiny, under the rule of Powell v. Alabama, 287 U. S. 45 (1932).

86. One presently unsettled question is whether a prisoner can waive arraignment or the illegality of his detention so as to render his confession admissible. In United States v. Haupt, 136 F. (2d) 661 (C. C. A. 7 th, 1943) written waivers of custody were voluntarily given. The court, however, rejected confessions obtained during the period of illegal detention on the grounds that the duties imposed by law on officers maling arrests could not be waived. Defendants had had no opportunity to consult counsel.

In United States v. Grote, 140 F. (2d) 413 (C. C. A. 2d, 1944) a similar waiver vas signed. The court admitted the defendant's confession on the tenuous rationale that the accused was not under arrest at the time of making the statements. However, in the IIitckell case, the Supreme Court intimated that an oral waiver did not make an otherwise illegal detention legal. 322 U. S. 65,70 (1944). It is hard to see why the fact that the waiver was written should make any difference.

87. The other presently available sanctions are (1) the private tort action for wrongiul imprisonment or abuse of legal process and (2) the threat of dismissal or discipline of a misfeasant officer by his superiors. The practical uselessness of these sanetions are discusssd in Menorandum, op. cit. supra note 22, at 17-1S.

88. See testimony of Circuit Judge Stephens, Hearings, op. cit. soffra note 1, at 13. 
possibly the jury on the conduct of the police rather than on the issuc of the accused's innocence or guilt. Even assuming the period of permissible detention were lengthened, a third disadvantage is that application of the $M c N a b b$ rule may lead to exclusion of confessions, although the trial judge is convinced they constitute trustworthy testimony..$^{80}$ Moreover, unless the Courts, by analogy to the "wire-tapping" cases," extended the $M c N a b b$ rule so as to keep out information obtained derivatively from statements made during an illegal detention, the exclusionary device is probably not a sufficiently strong sanction to prevent illegal detentions.

A more effective and judicious sanction than exclusion would be amenclment of the Judicial Code ${ }^{91}$ to include unlawful detention by federal officers among the contempts which can be summarily punished. If this were done, it would be desirable to amend the rigid $M c N a b b$ rule and vest in the federal judiciary discretion to exclude confessions obtained during illegal detentions, when the length of the delay or the character of imprisonment and examination created doubts as to the voluntariness of a confession. ${ }^{02}$

.89. See dissenting opinion of Mr. Justice Reed, McNabb v. United States, 318 U. S. 332, 347 (1943); United States v. Lee Hee, 60 F. (2d) 924 '(C. C. A. 2d, 1932); 3 Wrgmok:, Evidence (3d ed. 1940) §841; Comment (1943) 56 Harv. L. Rev. 1008.

90. The doctrine that statements overheard by "wire-tapping" are inadmissible in the federal courts, 48 Stat. 1103 (1934), 47 U. S. C. $\$ 605$ (1940); Nardone v. United States, 302 U. S. 379 (1937), has been extended to bar evidence obtained by use of hints obtained by wire-tapping. Nardone v. United States, 308 U. S. 338 (1939). However, the testimony of a witness, not a party to the communication, induced to testify by use of the intercepted material, is admissible. Goldstein v. United States, 316 U. S. 114 (1942).

In many states, the rule is that all evidence obtained by wire-tapping is admissible. Young v. Young, 56 R. I. 401, 185 Atl. 901 (1936); Leon v. State, 180 Md. 279, 23 A. (2d) 706 (1941), cert. denied, 316 U. S. 680 (1941).

91. 36 STAT. 1163 (1911), 28 U. S. C. \$ 385 (1940) limits the power of federal courts to punish contempts to instances of "misbehavior of any person in their presence, or so near thereto as to obstruct the administration of justice, the misbehavior of any of the officers of said courts in their official transactions, and the disobedience or resistance by any such officer, or by any ... other person to any lawful writ, process, order, rule, decree, or command of the said courts."

92. See State v. Browning, 178 S. W. (2d) 77 (Ark. Sup. Ct. 1944). 